\title{
STRUCTURAL AND SPECIES DIVERSITY OF FOREST LANDSCAPE PHYTOCENOSES OF WATER-GLACIAL PLAINS (WITHIN THE PENZA REGION)
}

\author{
N. A. Leonova \\ Penza State University, 40 Krasnaya street, Penza, 440026, Russia \\ E-mail:na_leonova@mail.ru
}

Abstract. Background. Position of the Penza region has played the leading role in the formation of its landscapes: it lies within the Oka-Don plain and the west slopes of the Volga upland. Landscapes of water-glacial plains are common in the northwest of the Penza region, in the marginal part of the Oka-Don lowland. The border between the Oka-Don plain and the Volga upland is indistinct and is currently not reflected in the relief. In general, the landscapes of the Oka-Don plain differ significantly from the landscapes of the Volga upland, which obviously should be also reflected in phytocenosis species composition and structure. Information about the vegetation of this territory is scarce, therefore this publication aims at analyzing the current state of vegetation cover of foreststeppe landscapes of water-glacial plains within the boundaries of the Penza region. Materials and methods. Floral composition and structure of broad-leaved forests were analyzed in route and stationary studies on test plots of $100 \mathrm{~m}^{2}$ each. The structural diversity of communities was assessed by the ratio of ecological-coenotic groups (ECGs) of species in the vegetation cover. Classification of communities was carried out according to the principle of dominance, taking into account ecological-coenotic groups, as well as in accordance with the principles of floristic classification. Results. The modern vegetation cover of water-glacial plain landscapes within the Penza region is mainly represented by forests. Birch and aspen forests predominate, while pine forests occupy about a quarter of the territory, and broad-leaved forests with a high participation of oak account for about $10 \%$. Linden forests and maple forests (Norway maple) occupy rather small areas. Near springs, streams, along the floodplains of small rivers, black alder forests are formed, whereas around swamps (mostly with traces of anthropogenic activity in terms of drainage) willow forests appear. Vegetation classification was carried out, and the confinement of assigned classification units to different types of locality was recorded. Conclusions. Active economic activity in the landscapes of water-glacial plains has led to a significant transformation of vegetation cover. Much of the watershed has been ploughed and converted into farmland. Boreal pine forests are a rare type of forest in the Penza region. Their communities include some species that are extremely rare for the region.

Keywords: water-glacial plain, ecological-coenotic groups, vegetation classification, rare plant species, pine forests, birch forests, broad-leaved forests, aspen forests, black alder forests.

For citation: Leonova N.A. Structural and species diversity of forest landscape phytocenoses of water-glacial plains (within the Penza oblast). Russian Journal of Ecosystem Ecology. 2020;5(1). Available from: https://doi.org/10.21685/2500-0578-2020-1-4

\section{ХАРАКТЕРИСТИКА СТРУКТУРНОГО И ВИДОВОГО РАЗНООБРАЗИЯ ФИТОЦЕНОЗОВ ЛЕСНЫХ ЛАНДШАФТОВ ВОДНО-ЛЕДНИКОВЫХ РАВНИН (В ГРАНИЦАХ ПЕНЗЕНСКОЙ ОБЛАСТИ)}

\section{Н. А. Леонова}

Пензенский государственный университет, Россия, 440026, г. Пенза, ул. Красная, 40 E-mail:na_leonova@mail.ru

Аннотация. Актуальность и цели. Ведущую роль в формировании ландшафтов Пензенской области сыграл позиционный фактор: это положение в пределах Окско-Донской равнины и западных склонов Приволжской возвышенности. Ландшафты водно-ледниковых равнин распространены на северо-западе Пензенской области, в краевой части Окско-Донской низменности. Граница между Окско-Донской равниной и Приволжской возвышенностью нечеткая и в современном рельефе не выражена. В целом ландшафты Окско-Донской равнины существенно отличаются от ландшафтов Приволжской возвышенности, что очевидно должно найти отражение и в видовом составе и структуре фитоценозов. Сведения о растительности этой территории немногочисленны, поэтому настоящая публикация ставит своей целью анализ современного состояния растительного покрова лесостепных ландшафтов водно-ледниковых равнин в границах Пензенской области. 
Материалы и методы. Изучение флористического состава и структуры широколиственных лесов проводили

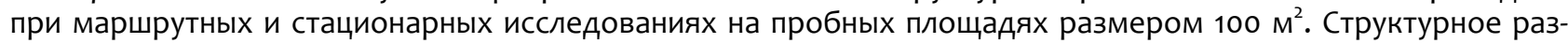
нообразие сообществ оценивали по соотношению эколого-ценотических групп (ЭЦГ) видов в составе растительного покрова. Классификацию сообществ проводили по доминантному принципу с учетом экологоценотических групп, а также в соответствии с принципами флористической классификации. Результаты. Современный растительный покров ландшафтов водно-ледниковых равнин в границах Пензенской области представлен в основном лесами. Преобладают березняки и осинники, сосняки занимают около четверти территории, широколиственные леса с высоким участием дуба черешчатого - около 10 \%. Незначительными по площади участками встречаются липняки, кленовники (из клена остролистного). Вблизи родников, ручьев, по поймам малых рек формируются черноольшаники, вокруг болот (большей частью со следами антропогенной деятельности - осушением) - ивняки. Проведена классификация растительности, отмечены приуроченности выделенных классификационных единиц к типам местности. Выводы. Интенсивная хозяйственная деятельность в ландшафтах водно-ледниковых равнин привела к существенной трансформации растительного покрова. Значительная часть водораздельных территорий распахана и преобразована в сельхозугодья. Редкими для Пензенской области являются сосняки бореальные. В составе их сообществ отмечены очень редкие для области виды.

Ключевые слова: водно-ледниковая равнина, эколого-ценотические группы, классификация растительности, редкие виды растений, сосняки, березняки, широколиственные леса, осинники, черноольшаники.

\section{Introduction}

The boundary position of the Penza region (on the west slopes of the Volga upland and the OkaDon plain) plays an important role in the formation of its landscapes. Forest-steppe landscapes of water-glacial plains are located in the northwest of the Penza region (within the boundaries of the $\mathrm{Ze}$ metchinsky district) in the marginal part of the Oka-Don plain. The border between the Oka-Don plain and the Volga upland is indistinct and is currently not reflected in the relief. The landscapes of the Oka-Don plain differ significantly from those of the Volga upland within the Penza region. Erosive landforms in the thickness of fluvioglacial sands are relatively shallow and have gentle slopes and wide bottoms. The lowland is composed of uneven-grained sands with lenses of clays and rare inclusions of pebbles of crystalline rocks. Ground water usually lies at a depth of $2-5 \mathrm{~m}$, sometimes up to $10 \mathrm{~m}$. Poorly drained interfluvial spaces are often waterlogged. The features of the lithogenic base play into weak resistance to the development of waterlogging, suffusion and deflation. Absolute elevation does not exceed $180 \mathrm{~m}$. Landscapes of water-glacial plains are common here [1-3] and watershed types of locality prevail:

Type 1 - poorly drained, slightly undulating interfluvial areas composed of a thick layer of fluvioglacial deposits lying on morainic loams with sod-podzolic and grey forest soils.

On watersheds, medium-grained and finegrained sands are subject to suffusion processes (erosion of fine particles with the formation of rounded or oval subsidence forms), which results in the formation of hydromorphic hollow inclusions. The landscape pattern combines hydrogenic elements of suffusion hollows and lithogenic elements of inter-hollow spaces (Fig. 1).

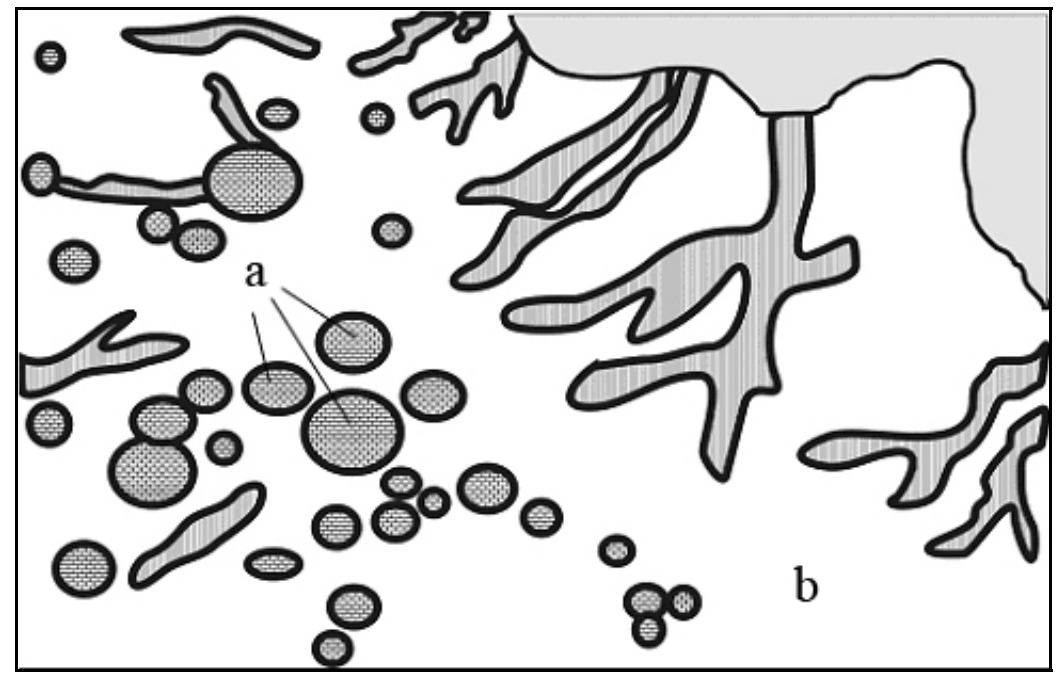

Fig. 1. Landscape pattern of slightly undulating interfluvial spaces composed of a thick layer of fluvioglacial deposits on morainic loams:

$a$ - hydrogenic landscape of suffusion hollows; $b$ - lithogenic landscape of inter-hollow spaces 
Type 2 - slightly undulating interfluvial spaces composed of shallow fluvioglacial deposits with grey forest and chernozem soils. Unlike in type 1, close morainic loams play a large role in soil formation processes, whereas the role of suffusion pro- cesses in relief formation decreases, and the role of erosion and landslide processes increases. The landscape pattern combines watersheds, floodplains of small rivers and streams, hollows on the slopes of river valleys, and inter-gulch spaces (Fig. 2).

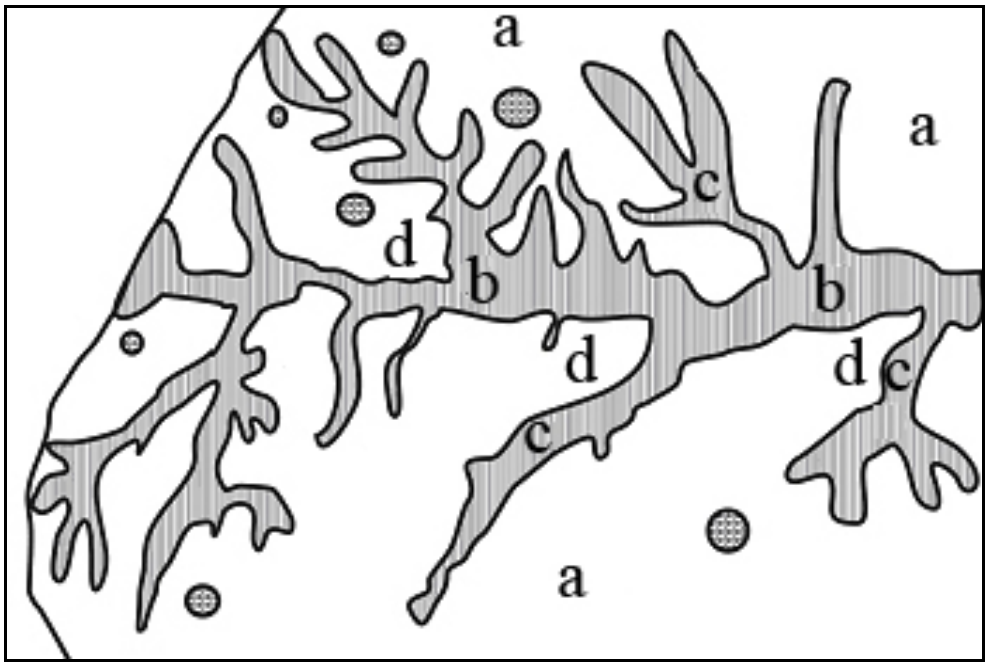

Fig. 2. Landscape pattern of slightly undulating interfluvial spaces composed of shallow fluvioglacial deposits lying on morainic loams: $a$ - watersheds;

$b$ - floodplains of small rivers and streams; $c$ - dells on the slope of river valleys; $d$-inter-gulch spaces

According to the botanical and geographical zoning, the territory belongs to the Tsninsky floral region, which has the richest complex of rare (mainly forest and wetland) species [4], and Vyshe-Mokshansky [5] floral region.

Information about the vegetation of the OkaDon plain within the boundaries of the Penza region is scarce. Vegetation study of part of this territory was conducted by V. V. Alyokhin [6] in the early 20th century. The structure of vegetation cover is roughly shown on the "Vegetation Map" of the Penza region [7].

The objective of this work is to analyze the current state of vegetation cover of forest-steppe landscapes of water-glacial plains in the Penza region.

\section{Methods of research}

Vegetation of the landscapes of water-glacial plains within the Penza region was examined using the route method. In 2011-2018, more than 800 geobotanical descriptions were carried out on test plots (TPs) of $100(10 \times 10) \mathrm{m}^{2}$. Names of vascular plants are given according to S. K. Cherepanov [8].

To analyze the structure of the grass-dwarf shrub layer, all types of vascular plants were divided into 8 ECGs (ecological-coenotic groups): nemoral $(\mathrm{Nm})$, boreal $(\mathrm{Br})$, nitrophilous $(\mathrm{Nt})$, oligotrophic $(\mathrm{Og})$, piny $(\mathrm{Pn})$, steppe $(\mathrm{St})$, meadowforest edge (Md), and wetland (Wt) [9].

The obtained geobotanical descriptions served as the basis for identifying syntaxons according to the principle of dominance, taking into account ecologi- cal-coenotic groups [10], as well as in accordance with the principles of floristic classification $[11,12]$.

Formations were determined by tree layer dominants. Association groups were identified based on the dominance of one or more ECGs in the ground cover (based on a complete floral list of vascular plants of the grass-dwarf shrub layer).

Taking into account species dominating the tree layer, the following formations and groups of association were identified: pine forests - forests where Pinus sylvestris is the tree-stand edificator, aspen forests - those dominated by Populus tremula, birch forests - forests dominated by Betula pendu$l a$ and B. pubescens, alder (black alder) forests forests dominated by Alnus glutinosa, and the group of broad-leaved forest formations - forests with the predominance of Quercus robur, Tilia cordata, and Fraxinus excelsior.

\section{Results and discussion}

The current vegetation cover of the Oka-Don plain within the Penza region consists mainly of forests. Grass vegetation (steppificated, mesophytic and hygrophytic meadows) can be found along river valleys and ravine slopes. Birch (42.5\%), pine $(25.4 \%)$ and aspen $(18.9 \%)$ forests predominate; broad-leaved forests with a high participation of the common oak occupy $10.2 \%$. Linden and maple forests are only found on small areas (linden forests $-0.45 \%$, forests of Norway maple $0.01 \%)$. Black alder forests $(1.7 \%)$ grow near springs, streams, along the floodplains of small 
rivers, whereas willow forests $(0.03 \%)$ appear around swamps (mostly with traces of anthropogenic activity in terms of drainage). Siberian spruce $(0.06 \%)$, larch $(0.16 \%)$, common ash $(0.23 \%)$, poplars $(0.23 \%)$, and cedar $(0.01 \%)$ are also found.

A significant part of watershed areas (especially the interfluvial spaces composed of shallow fluvioglacial deposits) has been ploughed and converted into farmland (some of which is currently abandoned). The forest cover percentage of the area is about $40 \%$. There is natural overgrowth of fallow lands with Betula pendula and Pinus sylvestris. Figures 3 and 4 show diagrams and maps of plant communities' distribution by selected types of locality.

According to the floristic classification, the forests of the Oka-Don plain in the Penza region belong to 4 classes, 4 orders, 5 alliances and 8 associations [13]:

Класс Vaccinio-Piceetea Br.-Bl. in Br.-Bl., Siss. et Vlieger 1939

Порядок Pinetalia sylvestris Oberdorfer 1957

Союз Dicrano-Pinion sylvestris (Libbert 1933) Matuszkiewicz 1962

Acc. Cladonio rangiferinae-Pinetum sylvestris Juraszek 1927

Acc. Querco roboris-Pinetum sylvestris J. Mat. 1988 sensu Morozova 1999

Acc. Molinio caeruleae - Pinetum sylvestris (Schmid. 1936) em Mat. 1973

\section{фация Betuleosum pendulae}

фация Populeosum tremulae

Класс Querco-Fagetea Br.-Bl. et Vlieg. in Vlieg. 1937

Порядок Fagetalia sylvaticae Pawłowski et al. 1928

Союз Querco roboris- Tilion cordatae Solometch et Laivinsh ex Bulokhov et Solomeshch 2003

Acc. Corylo avellanae-Pinetum sylvestris Bulokhov et Solomeshch 2003
Acc. Mercurialo perennis-Quercetum roboris Bulokhov et Solomeshch 2003

\section{фация Betuleosum pendulae}

фация Populeosum tremulae

Союз Alnion incanae Pawłowski, Sokołowski et Wallisch 1928

Acc. Urtico dioicae-Alnetum glutinosae Bulokhov et Solomeshch 2003

Класс Oxycocco-Sphagnetea Br.-Bl. et Tx. ex Westhof et al. 1946

Порядок Sphgno-Betuletalia Scamoni et Passarge 1959

Союз Betulion pubescentis Lohm. et Tx. ex Oberdorftr 1957

Acc. Vaccinio uliginosi-Betuletum pubescentis Libb. 1933

Класс Alnetea glutinosae Br.-Bl. et Tx. ex Westhoff et al. 1946

Порядок Alnetalia glutinosae Tx. 1937

Союз Alnion glutinosae Malcuit 1929

Acc. Carici elongatae-Alnetum glutinosae Koch 1926 ex Tx. 1931

Modern pine forests are found only in interfluvial spaces composed of a thick layer of fluvioglacial deposits (within type 1 of locality). They account for up to $25 \%$ of the forested area, and a third of them are of artificial origin.

There are not much detailed data on the composition and state of pine forests in the last century on the territories of water-glacial plains that are now part of the Penza region (formerly Spassky uyezd of Tambov guberniya). V. V. Alyokhin [6], stating that pine forests in the Tambov guberniya were underexplored, noted that they are confined to "sandy spaces, mostly to river valleys". However, he emphasizes that throughout the Tambov guberniya, "pine forests decrease in area, being replaced by broad-leaved forests of various types, and this process is likely entirely due to the destructive activity of man, since the felled pine forest sometimes is not naturally restored at all".

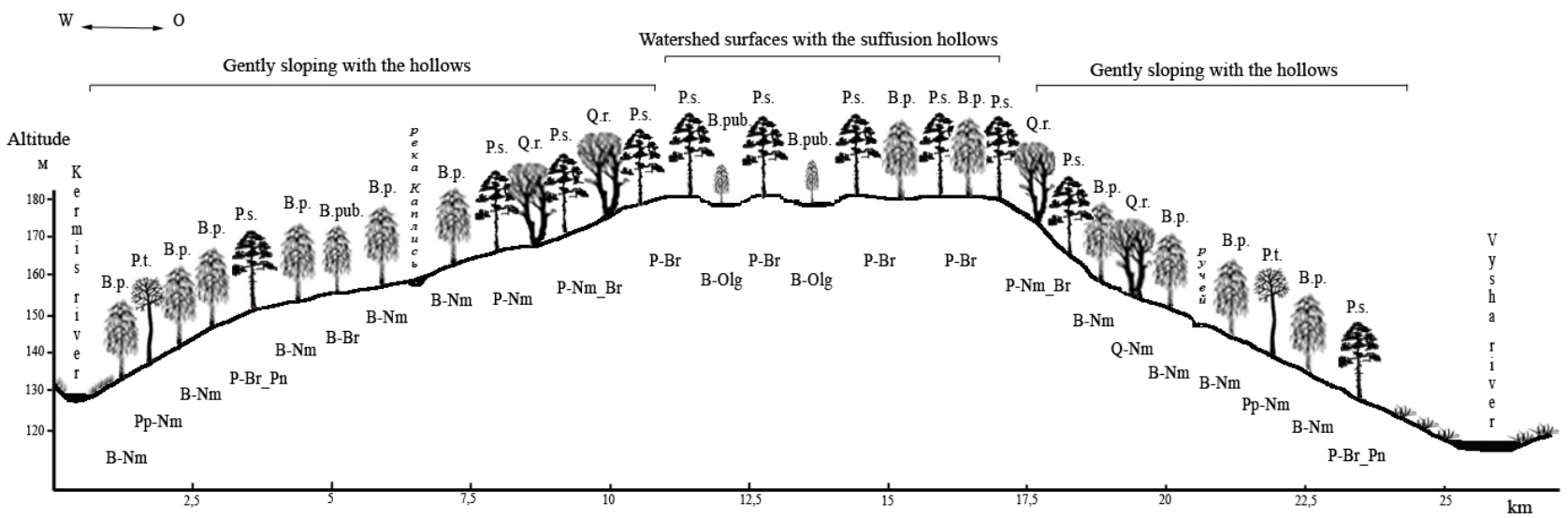

Fig. 3. Scheme of distribution of association groups of the main forest formations along the lines from east to west within type 1 of locality (poorly drained interfluvial areas composed of a thick layer of fluvioglacial deposits)

Ttrees and shrubs: Q.r. - Quercus robur, P.s. - Pinus silvestris,

B.pen. - Betula pendula, B.pub. - Betula pubescens, P.t. - Populus tremula.

Association groups: $\mathrm{P}-\mathrm{Br}$ - boreal pine forests (Pineta boreoherbosa), $\mathrm{P}-\mathrm{Nm} \mathrm{Br}$ - nemoral-boreal

pine forests (Pineta nemoro-boreo-herbosa), $\mathrm{P}-\mathrm{Nm}$ - nemoral pine forests (Pineta nemoro-herbosa),

$\mathrm{P}-\mathrm{Br}$ Pn - boreal-piny forests (Pineta boreo-pine-herbosa), B-Nm - nemoral birch forests (Betuleta

nemoro-herbosa), $\mathrm{B}-\mathrm{Br}$ - boreal birch forests (Betuleta boreo-herbosa), $\mathrm{B}$-Olg - oligotrophic birch forests

(Betuleta olygotropho-herbosa), Pp-Nm - nemoral aspen forests (Tremuleta nemoro-herbosa) 


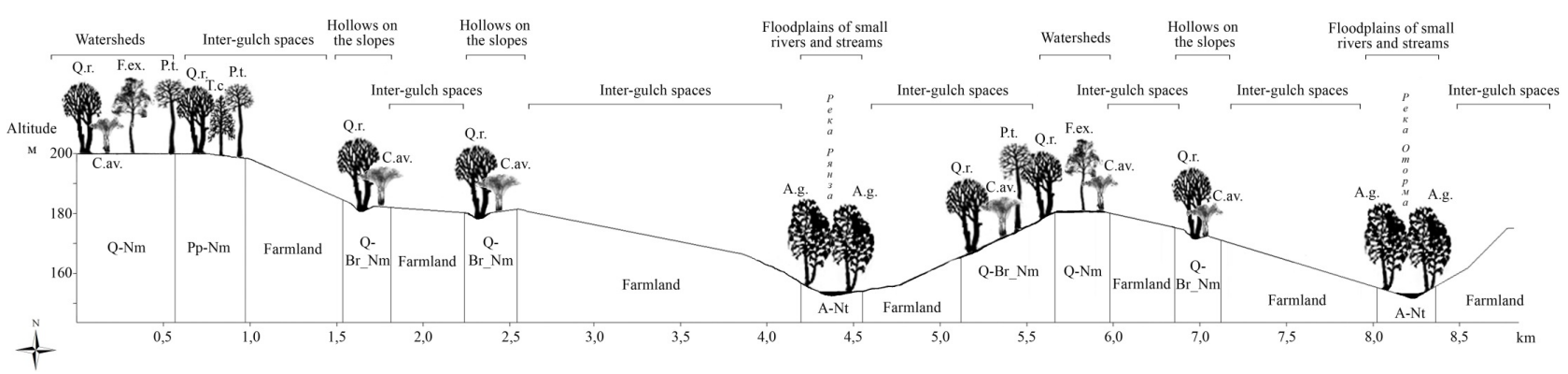

Fig. 4. Scheme of distribution of association groups of the main forest formations along the lines from northeast to southwest within type 2 of locality (interfluvial spaces composed of shallow fluvioglacial deposits)

Ttrees and shrubs: Q.r. - Quercus robur, P.t. - Populus tremula, F.ex. - Fraxinus excelsior, T.c. - Tilia cordata, A.g. - Alnus glutinosa, C.av. - Corylus avellana.

Association groups: Q-Nm - nemoral broad-leaved forests (Querceta nemoro-herbosa),

Q-Br_Nm - boreal-nemoral broad-leaved forests (Querceta boreo-nemoro-herbosa),

$\mathrm{Pp}-\mathrm{Nm}$ - nemoral aspen forests (Tremuleta nemoro-herbosa), A-Nt - nemoral-nitrophilous alder forests

(Alneta nitrophilo-herbosa), A-Wt - wetland alder forests (Alneta aqua-uliginoso-herbosa)

According to the dominance of ECGs in the ground cover of modern pine forests, the following groups of associations were identified: boreal pine forests - Pineta boreo-herbosa (P-Br), nemoralboreal pine forests - Pineta nemoro-boreo- herbosa $(\mathrm{P}-\mathrm{Nm} \mathrm{Br})$, nemoral pine forests - Pineta nemoro-herbosa $\overline{\boldsymbol{a}}(\mathrm{P}-\mathrm{Nm})$, boreal pine forests with high participation of pine species - Pineta pineboreo-herbosa (P-Pn_Br), and boreal-piny forests Pineta boreo-pine-herbosa $\left(\mathrm{P}-\mathrm{Br} \_\mathrm{Pn}\right)($ Table 1).

Table 1

Species diversity and highly constant species of groups of associations, pine stand formation (Pineta sylvestris)

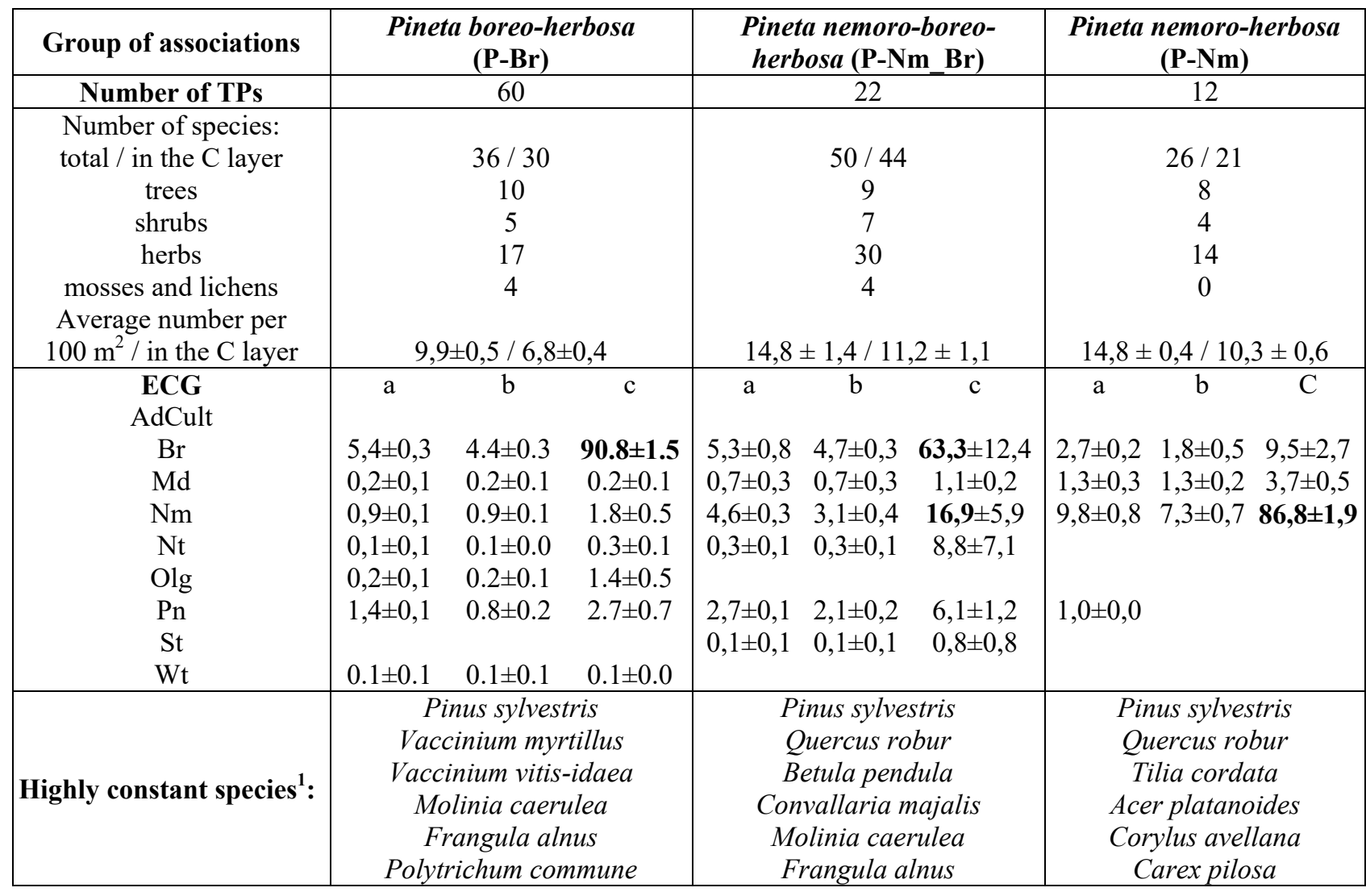

Note. $\mathrm{a}$ - the average number of species per TP in all layers; $\mathrm{b}$ - the average number of species per TP in the $\mathrm{C}$ lay$\mathrm{er} ; \mathrm{c}-$ the proportion of species in the $\mathrm{C}$ layer, taking into account the average abundance for the TP.

${ }^{1}$ - species constancy is calculated without considering layers; prevailing ECGs are highlighted in bold, taking into account the abundance of species. 
Table 1 (continuation)

Species diversity and highly constant species of groups of associations, pine stand formation (Pineta sylvestris)

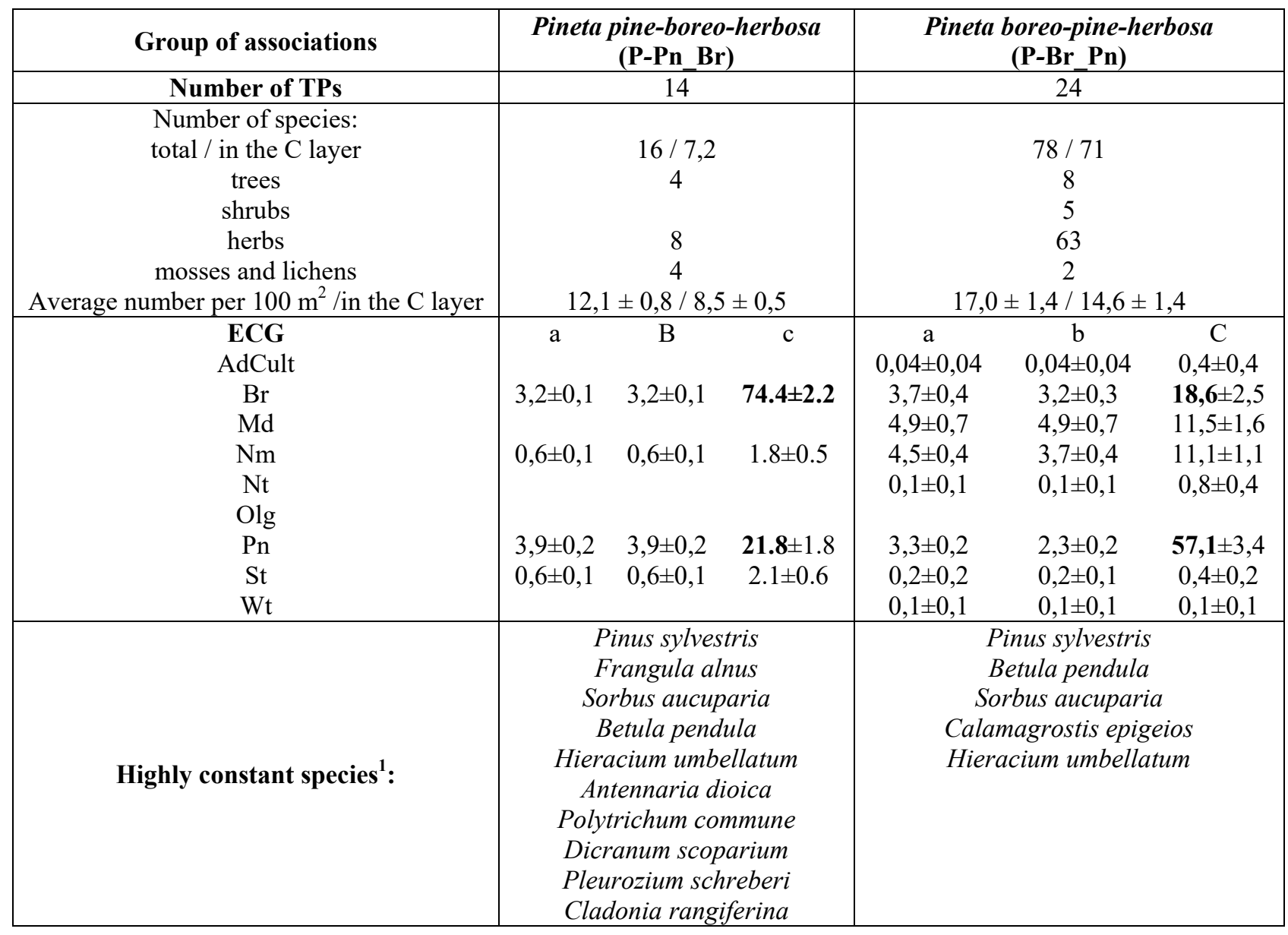

Pinus sylvestris, Betula pendula, B. pubescens, Populus tremula, and Quercus robur are found in the tree stand. Very rarely the stand contains individual young generative trees of Picea abies of normal vitality as a result of them being planted under the crowns of Pinus sylvestris. Despite the annual formation of quite a large number of cones, no undergrowth of seed-origin Picea abies is found. In general, Picea abies trees in this part of the region are not rare, but very short-lived: there is a fairly rapid (after 5-10 years of life) mass drying of trees and the formation of standing dead trees. At the same time, according to V. V. Alyokhin [6], at the beginning of the past century, wild Picea abies was found on this territory in large numbers in all forest districts. "Twinflower (Linnaea borealis), a very typical plant of spruce forests", was "also found". At the same time, the author mentions the mass loss of spruce. The following reasons are listed: evidence of tree infestation by spruce bark beetles (especially grave in the $1880 \mathrm{~s}-1890 \mathrm{~s}$ ), as well as climate change and "changed general conditions of existence".

A special feature of the formation is the presence of green mosses, which in 2 groups of associ- ations of 5 (boreal pine forests and boreal pine forests with high participation of piny species) make a fairly well-defined layer and which are occasionally found in nemoral-boreal pine forests.

Plant communities belonging to the Pineta boreo-herbosa association group are found only on watershed surfaces between the suffusion hollows and occupy significant areas (about $40 \%$ of the area occupied by pine forests) (See Fig. 3). All of them are affected by economic activity, i.e. logging, grazing, as well as rather frequent fires. A distinctive feature of boreal pine forests of the Oka-Don plain is the predominance of shrubs in the ground cover and the participation of green mosses with complete absence of evergreen herbaceous plants. The species composition and abundance of green mosses have been significantly affected by economic activity and fires. Of the green moss species, Polytrichum commune is found most frequently and with great abundance in boreal pine forests, apparently due to its ability to grow after fires, whereas Pleurozium schreberi and Dicranum scoparium are also common. Sphagnum girgensohnii is found in microhollows in small clusters. Rubus nessensis, Ledum palustre, and Calluna vul- 
garis, which are very rare species for the Penza region, are found only as part of boreal pine forests [14]. For the former two above-named species this is one of the two habitats in the region that have been preserved to date, whereas Calluna vulgaris is not found anywhere else in the region. Populations of Rubus nessensis in these conditions are numerous and full-fledged and the species plays a significant role in the undergrowth (in the rest of the region, this species is extremely rare and is recorded only in one more habitat).

Nemoral-boreal pine forests - Pineta nemoro-boreo-herbosa $\left(\mathrm{P}-\mathrm{Nm} \_\mathrm{Br}\right)$ - are typical for the near-watershed slopes of the north, east, and west exposure (See Fig. 3) and are quite common in the territory under consideration. All of them are affected by economic activity, i.e. logging, grazing, as well as rather frequent fires. This group of associations is transitional from boreal to nemoral pine forests.

Nemoral pine forests - Pineta nemoroherbosa $(\mathrm{P}-\mathrm{Nm})$ - are not often found on the OkaDon plain within the Penza region and are confined to smooth near-watershed slopes (See Fig. 3). A distinctive feature of nemoral pine trees is the low diversity of ECGs - 4, with absolute predominance of species of the nemoral ECG both in terms of the number of species and their abundance (See Table 1).

Boreal pine trees with a high participation of pine-forest species - Pineta pine-boreo-herbosa (P-Pn_Br) - occur sporadically in small patches on the upper parts of the near-watershed slopes of the south exposure. This group of associations is transitional from boreal to boreal-piny pine forests. A distinctive feature of Pineta pine-boreo-herbosa is the predominance of green mosses and Cladonia rangiferina in the ground cover, as well as the presence of immature undergrowth of Pinus sylvestris.

Boreal-piny pine forests - Pineta boreo-pineherbosa $(\mathrm{P}-\mathrm{Br} \mathrm{Pn})$ are quite rare and are confined to watershed surfaces and upper parts of the near- watershed slopes of the south exposure (See Fig. 3). Plant communities of this group of associations are usually formed after various anthropogenic impacts, most often after ground fires, and are at various stages of succession development. Pine forests of silvicultural origin are also included in this group of associations. The grass-dwarf shrub layer shows the maximum species diversity among all pine forests. Beside the dominant species of the boreal and piny ECGs, there is a high participation of nemoral and meadow species with a low abundance (See Table 1). Thus, the number of nemoral, meadow and boreal species is similar, but the participation of species of the first two ECGs is 5 times less.

Modern broad-leaved forests are much less common in the landscapes of water-glacial plains than pine forests. Communities with the tree stands dominated by Quercus robur, Acer platanoides, Tilia cordata, and Fraxinus excelsior are found on slightly undulating interfluvial spaces composed of shallow fluvioglacial deposits (type 2 of locality).

There are very little data on the state of broadleaved forests in these territories in the past century. When examining the vegetation cover of the east part of the Tambov guberniya, V. V. Alyokhin [6] did not give detailed characteristics of broadleaved forests, but he noted that the estate of duchess Dolgorukaya, to the south of Zemetchino, had the "Dubrova" oak plantation consisting exclusively of old oaks without admixture of other trees and almost without undergrowth. On the southern edge of the plantation he revealed representatives of the steppe flora.

In the modern vegetation cover in the group of broad-leaved forest formations, the following groups of associations are identified (Table 2): nemoral broad-leaved forests - Querceta nemoro-herbosa (Q-Nm), boreal-nemoral broad-leaved forests Querceta boreo-nemoro-herbosa ( $\mathrm{Q}-\mathrm{Br}$ - Nm), meadow-nemoral broad-leaved forests - Querceta prato-nemoro-herbosa (Q-Md_Nm).

Table 2

Species diversity and highly constant species of groups of associations broad-leaved forest formations

\begin{tabular}{|c|c|c|c|}
\hline Group of associations & $\begin{array}{c}\text { Querceta nemoro-herbosa } \\
\mathrm{Q}-\mathrm{Nm}\end{array}$ & $\begin{array}{c}\text { Querceta boreo-nemoro- } \\
\text { herbosa }(\mathrm{Q}-\mathrm{Br} \text { Nm) }\end{array}$ & $\begin{array}{c}\text { Querceta prato-nemoro- } \\
\text { herbosa }(\mathrm{Q}-\mathrm{Md} \text { NNm) }\end{array}$ \\
\hline Number of TPs & 40 & 71 & 10 \\
\hline Number of species: & $44 / 39$ & $30 / 27$ & $9 / 6$ \\
total / in the C layer & 12 & 9 & 1 \\
Trees & 5 & 5 & 4 \\
Shrubs & 27 & 16 & \\
Herbs & & & $7,8 \pm 0,3 / 5,4 \pm 0,3$ \\
mosses and lichens & $13,6 \pm 0,5 / 9,3 \pm 0,4$ & $13,3 \pm 0,4 / 9,7 \pm 0,4$ & \\
Average number per & & & \\
$100 \mathrm{~m}^{2}$ /in the C layer & &
\end{tabular}


Table 2 (continuation)

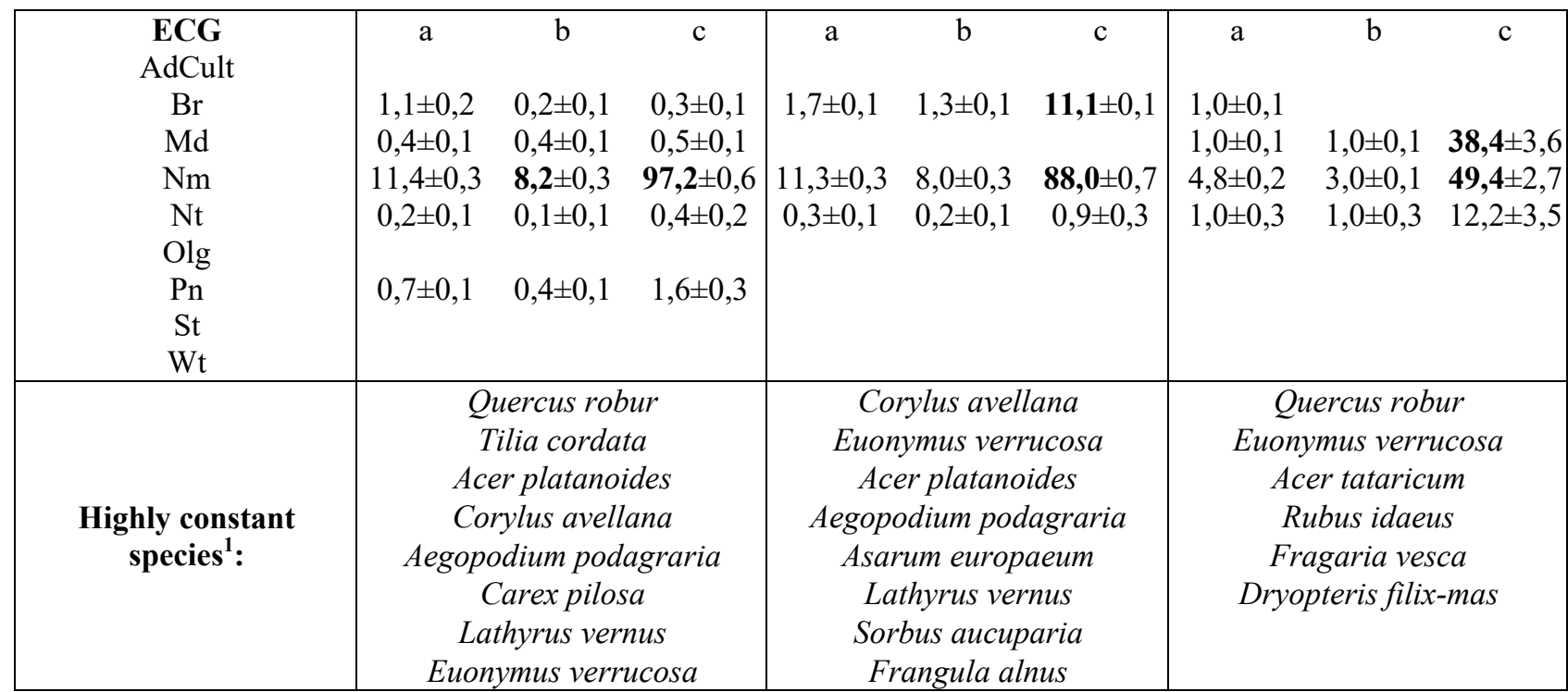

Note. $\mathrm{a}$ - the average number of species per TP in all layers; $b$ - the average number of species per TP in the C layer; $\mathrm{c}$ - the proportion of species in the $\mathrm{C}$ layer, taking into account the average abundance for the TP.

${ }^{1}$ - species constancy is calculated without considering layers; prevailing ECGs are highlighted in bold, taking into account the abundance of species.

\section{Nemoral-herbal broad-leaved forests -} Querceta nemoro-herbosa (Q-Nm) (See Table 2) are typical of watershed surfaces of type 2 of locality (slightly undulating interfluvial spaces composed of shallow fluvioglacial deposits) (See Fig. 4) and are found in small areas on the near-watershed slopes of the north, east and west exposure of type 1 of locality (slightly undulating interfluvial spaces composed of a powerful thickness thick mass of fluvioglacial deposits). Communities are often formed after selective logging of Quercus robur. Such forests are characterized by a 2-layer stand, dense undergrowth (Corylus avellana, Euonymus verrucosa), and sometimes a dense canopy of virginile undergrowth of Acer platanoides and Tilia cordata. Ground cover in these forests is heavily shaded; it is dominated by shadetolerant nemoral species (See Table 2). The absolute dominant is Carex pilosa, there are also Aegopodium podagraria and Lathyrus vernus plants.

Boreal-nemoral broad-leaved forests - Querceta boreo-nemoro-herbosa ( $\mathrm{Q}-\mathrm{Br} \mathrm{Nm})$ (See Table 2) occur mainly within type 2 of locality (slightly undulating interfluvial spaces composed of shallow fluvioglacial deposits) on the intergulch spaces and dells. Very rarely, small areas of these forests are found on the near-watershed slopes of type 1 of locality (slightly undulating interfluvial spaces composed of a thick mass of fluvioglacial deposits) (See vFig. 4).

Well-defined undergrowth is formed by Corylus avellana (dom.) and Euonymus verrucosa. The undergrowth of Sorbus aucuparia of all pre- generative age types is common. In most geobotanical descriptions, herbaceous plants of the nemoral ECG dominate in the grass-dwarf shrub layer, but the rather high abundance of Sorbus aucuparia boreal undergrowth in the layer does not allow us to consider them as part of Querceta nemoroherbosa so they are considered as part of the Querceta boreo-nemoro-herbosa group of associations.

Meadow-nemoral broad-leaved forests Querceta prato-nemoro-herbosa (Q-Md $\mathrm{Nm}$ ) are found within type 2 of locality. They occupy small areas and are have a small number of descriptions (See Table 2). They were formed as a result of economic activity, i.e. selective logging in nemoral broad-leaved forests and cattle grazing which led to the lightening of the lower layers, trampling of the ground cover and introduction of meadow species.

At present, aspen forests are quite common in forest-steppe landscapes of water-glacial plains. Those are mostly secondary forests formed after the felling of oak and pine forests.

In general, aspen forests occupy much larger areas on slightly undulating interfluvial spaces composed of shallow fluvioglacial deposits (type 2 of locality) (See Fig. 4).

According to the dominance of ECGs in the ground cover of modern aspen forests, the following groups of associations were identified: nemoral aspen forests - Tremuleta nemoro-herbosa (Pp$\mathrm{Nm}$ ), and boreal aspen forests - Tremuleta boreoherbosa $(\mathrm{Pp}-\mathrm{Br})$ (Table 3$)$. 
Species diversity and highly constant species of groups of associations, aspen stand formation (Populus tremula)

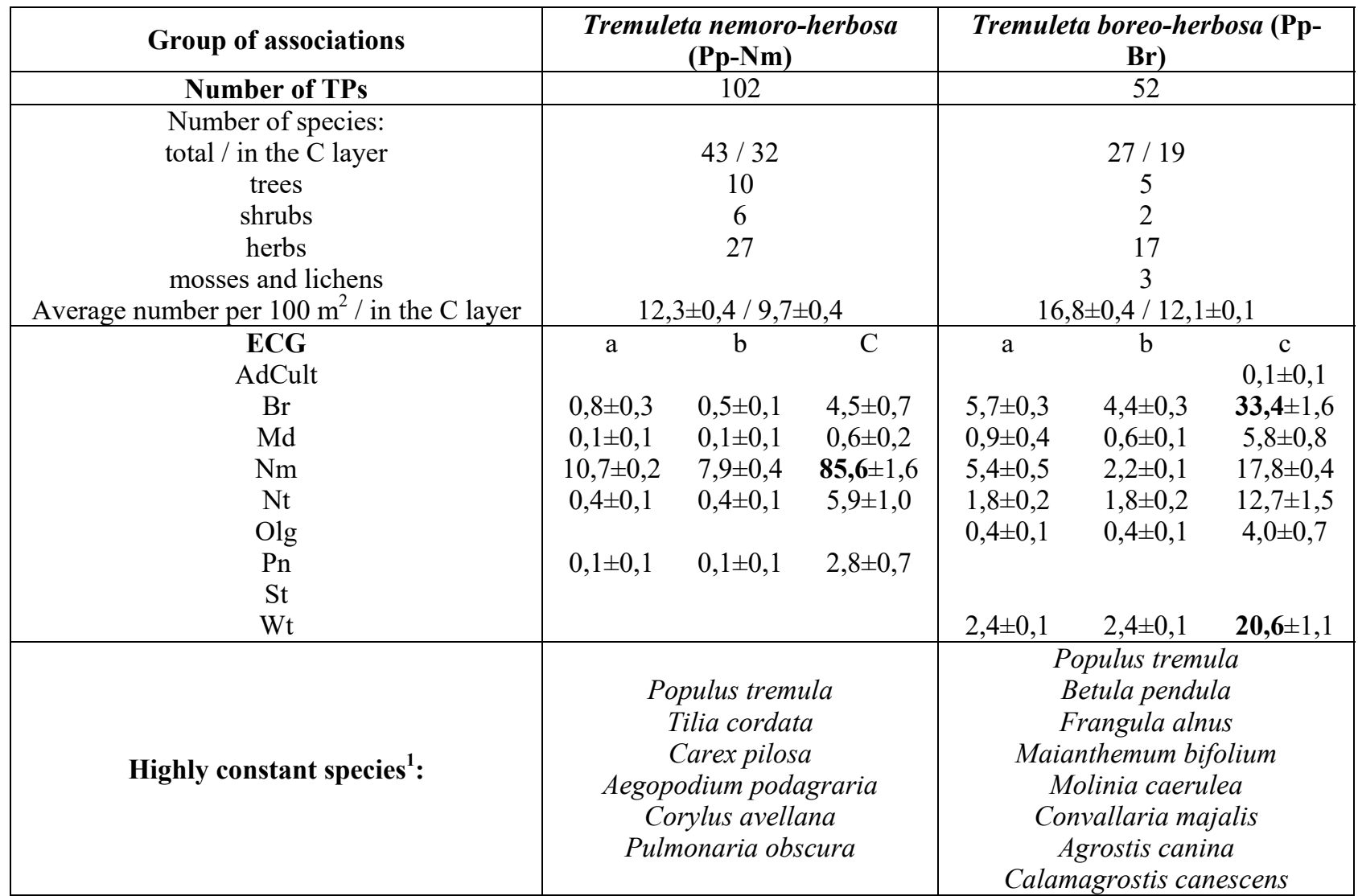

Note. $a$ - the average number of species per TP in all layers; $b$ - the average number of species per TP in the $C$ layer; $\mathrm{c}$ - the proportion of species in the $\mathrm{C}$ layer, taking into account the average abundance for the TP.

${ }^{1}$ - species constancy is calculated without considering layers; prevailing ECGs are highlighted in bold, taking into account the abundance of species.

Nemoral aspen forests - Tremuleta nemoroherbosa $(\mathrm{Pp}-\mathrm{Nm})$ are found throughout the territory of the Oka-Don plain in the Penza region (See Fig. 3, 4). They are the most common plant communities among the aspen forests of this territory. The tree layer is formed by Populus tremula with the participation of Quercus robur, Betula pendula, less often - Fraxinus excelsior, often there is a second tree layer of Tilia cordata and Acer platanoides. The undergrowth is dominated by Corylus avellana, which forms a fairly dense canopy. Communities with Acer platanoides and Tilia cordata in the undergrowth are much less common. The leading role in the number of species and projective cover is played by nemoral species (See Table 3). Dominant species of the herb-shrub layer are Aegopodium podagraria, Carex pilosa, and Stellaria holostea, which form corresponding associations.

Boreal aspen forests - Tremuleta boreoherbosa $(\mathrm{Pp}-\mathrm{Br})$ - are confined to watershed areas and watershed slopes of type 1 of locality and oc- cupy small areas. Stands are often two-layered: layer I is formed by Populus tremula and Betula pendula, whereas young generative Quercus robur trees are found in layer II. The undergrowth is formed by Frangula alnus, sometimes with low participation of Sorbus aucuparia and Lonicera xylosteum. The absolute dominant in the grass-dwarf shrub layer is Molinia caerulea. In $60 \%$ of descriptions, moss participation is recorded: Pleurozium schreberi, Polytrichum commune, and Sphagnum magellanicum, which form small singular clusters.

Forests dominated by birch stands (Betula pendula, B. pubescens) are currently predominant in the landscapes of water-glacial plains of the territory (See Fig. 3). Like aspen forests, birch forests are secondary plantations growing on felling sites, abandoned fallows, hay meadows, and burnt areas.

Analysis of the ecological-coenotic structure of the grass-dwarf shrub layer resulted in identification of the following groups of associations: boreal birch forests - Betuleta boreo-herbosa (B-Br), 
nemoral-boreal birch forests - Betuleta boreonemoro-herbosa (B-Br_Nm), boreal-nemoral birch forests - Betuleta nemoro-boreo-herbosa (B-Nm_Br), nemoral birch forests - Betuleta nemoro-herbosa (B-Nm), oligotrophic birch forests - Betuleta olygotropho-herbosa (B-Olg).

Boreal birch forests - Betuleta boreo-herbosa (B-Br) are quite widely represented within type 1 of locality (See Fig. 3): they are formed on the periphery of waterlogged depressions and grass swamps.

In addition to Betula pendula, Pinus sylvestris is also found in the tree layer. The undergrowth contains Salix myrsinifolia and Frangula alnus. The grass-dwarf shrub layer is dominated by species of the boreal ECG both in the number of species and projective cover (Table 4). Molinia caerulea dominates, and Vaccinium myrtillus occurs with high constancy. The moss cover is sparse, formed by Polytrichum commune and Sphagnum girgensohnii that form clusters of different sizes.

We assigned plant communities with codomination of nemoral and boreal species in the grass-dwarf shrub layer to 2 groups: nemoral-boreal birch forests - Betuleta nemoro-boreo-herbosa (B-Nm_Br) and boreal-nemoral birch forests - Betuleta boreo-nemoro-herbosa (B-Br_Nm). Associations of these groups have species composition and structure similar to their main groups (boreal and nemoral), and are obviously a phased transition from boreal to nemoral birch forests: $\mathrm{B}-\mathrm{Br}$ $\mathrm{B}-\mathrm{Nm} \mathrm{Br}-\mathrm{B}-\mathrm{Br} \mathrm{Nm}-\mathrm{B}-\mathrm{Nm}$.

Betuleta nemoro-boreo-herbosa (B-Nm $\mathrm{Br}$ ) occur quite often in small areas on watershed surfaces and near-watershed slopes of type 1 locality. Their formation is associated with logging of boreal pine forests. In the stand, in addition to Betula pendula with Pinus sylvestris participation forming tree layer I, Quercus robur is also typical in layer II. The undergrowth is poor and is formed by Frangula alnus. Undergrowth of Pinus sylvestris and nemoral tree species Tilia cordata and Quercus robur is typical. The sparse grass-dwarf shrub layer is dominated by boreal ECG species: Vaccinium myrtillus (dom.), Molinia caerulea, Melampyrum pratense, Vaccinium vitis-idaea, whereas there are no herbaceous species of other ECGs at all. However, because of the participation of nemoral tree species with high constancy and abundance such as Tilia cordata and Populus tremula in the undergrowth layer formation it is impossible to classify these forests as boreal; they are rather considered as transitional within the nemoral-boreal group. Boreal and nemoral species are considered to be highly consistent species and indicators of the group and association (See Table 4).

Table 4

Species diversity and highly constant species of groups of associations, birch stand formation (Betula pendula, B. pubescens)

\begin{tabular}{|c|c|c|c|c|c|c|}
\hline Group of associations & \multicolumn{3}{|c|}{ Betuleta boreo-herbosa (B-Br) } & \multicolumn{3}{|c|}{$\begin{array}{l}\text { Betuleta olygotropho-herbosa } \\
\text { (B-Olg) }\end{array}$} \\
\hline Number of TPs & \multicolumn{3}{|c|}{37} & \multicolumn{3}{|c|}{96} \\
\hline $\begin{array}{c}\text { Number of species: } \\
\text { total / in the C layer } \\
\text { trees } \\
\text { shrubs } \\
\text { herbs } \\
\text { mosses and lichens } \\
\text { Average number per } 100 \mathrm{~m}^{2} / \text { in the } \mathrm{C} \text { laver }\end{array}$ & & $\begin{array}{c}17 / 8 \\
3 \\
1 \\
11 \\
2 \\
0.2 / 52\end{array}$ & & & $\begin{array}{c}21 / 14 \\
2 \\
2 \\
14 \\
3 \\
0.1 / 3.8 \pm\end{array}$ & \\
\hline ECG & \multirow[t]{2}{*}{$\mathrm{a}$} & \multirow[t]{2}{*}{ B } & \multirow[t]{2}{*}{$\mathrm{c}$} & \multicolumn{2}{|c|}{\begin{tabular}{c|c}
$7,2 \pm 0,1 / 3,8$ \\
& $b$
\end{tabular}} & \multirow[t]{2}{*}{$\mathrm{c}$} \\
\hline AdCult & & & & & & \\
\hline $\mathrm{Br}$ & $3,3 \pm 0,2$ & $2,1 \pm 0,2$ & $\mathbf{6 1 , 6} \pm 2,5$ & $1,1 \pm 0,1$ & $0,2 \pm 0,1$ & $11,8 \pm 2,9$ \\
\hline $\mathrm{Md}$ & $0,9 \pm 0,1$ & $0,9 \pm 0,1$ & $12,1 \pm 1,9$ & & \multirow{4}{*}{$\begin{array}{l}0,1 \pm 0,1 \\
1,7 \pm 0,1\end{array}$} & \multirow{4}{*}{$\begin{array}{l}0,1 \pm 0,1 \\
62,2 \pm 2,1\end{array}$} \\
\hline $\begin{array}{l}\mathrm{Nm} \\
\mathrm{Nt}\end{array}$ & \multirow[b]{3}{*}{$0,8 \pm 0,1$} & \multirow{3}{*}{$0,2 \pm 0,1$} & \multirow[b]{3}{*}{$7,3 \pm 1,9$} & & & \\
\hline Olg & & & & $\begin{array}{l}0,1 \pm 0,1 \\
1,9 \pm 0,1\end{array}$ & & \\
\hline $\mathrm{Pn}$ & & & & $0,6 \pm 0,1$ & & \\
\hline $\begin{array}{c}\text { St } \\
\mathrm{Wt}\end{array}$ & & & $19,1 \pm 1,5$ & & $1,8 \pm 0,1$ & $25,9 \pm 0,9$ \\
\hline Highly constant species ${ }^{1}$ : & & $\begin{array}{l}\text { la pubes } \\
\text { inia caer } \\
\text { entilla er } \\
\text { us sylves } \\
\text { nium my }\end{array}$ & & $\begin{array}{l}\text { Spho } \\
\text { Calc }\end{array}$ & $\begin{array}{l}\text { lla pubesc } \\
\text { um magel } \\
\text { grostis ca } \\
\text { orum vag } \\
\text { us sylves }\end{array}$ & $\begin{array}{l} \\
\text { icum } \\
\text { cens } \\
\text { tum }\end{array}$ \\
\hline
\end{tabular}

Note. $\mathrm{a}-$ the average number of species per TP in all layers; $\mathrm{b}$ - the average number of species per TP in the C lay$\mathrm{er} ; \mathrm{c}-$ the proportion of species in the $\mathrm{C}$ layer, taking into account the average abundance for the TP.

${ }^{1}$ - species constancy is calculated without considering layers; prevailing ECGs are highlighted in bold, taking into account the abundance of species. 
Table 4. (continuation)

Species diversity and highly constant species of groups of associations, birch stand formation (Betula pendula, B. pubescens)

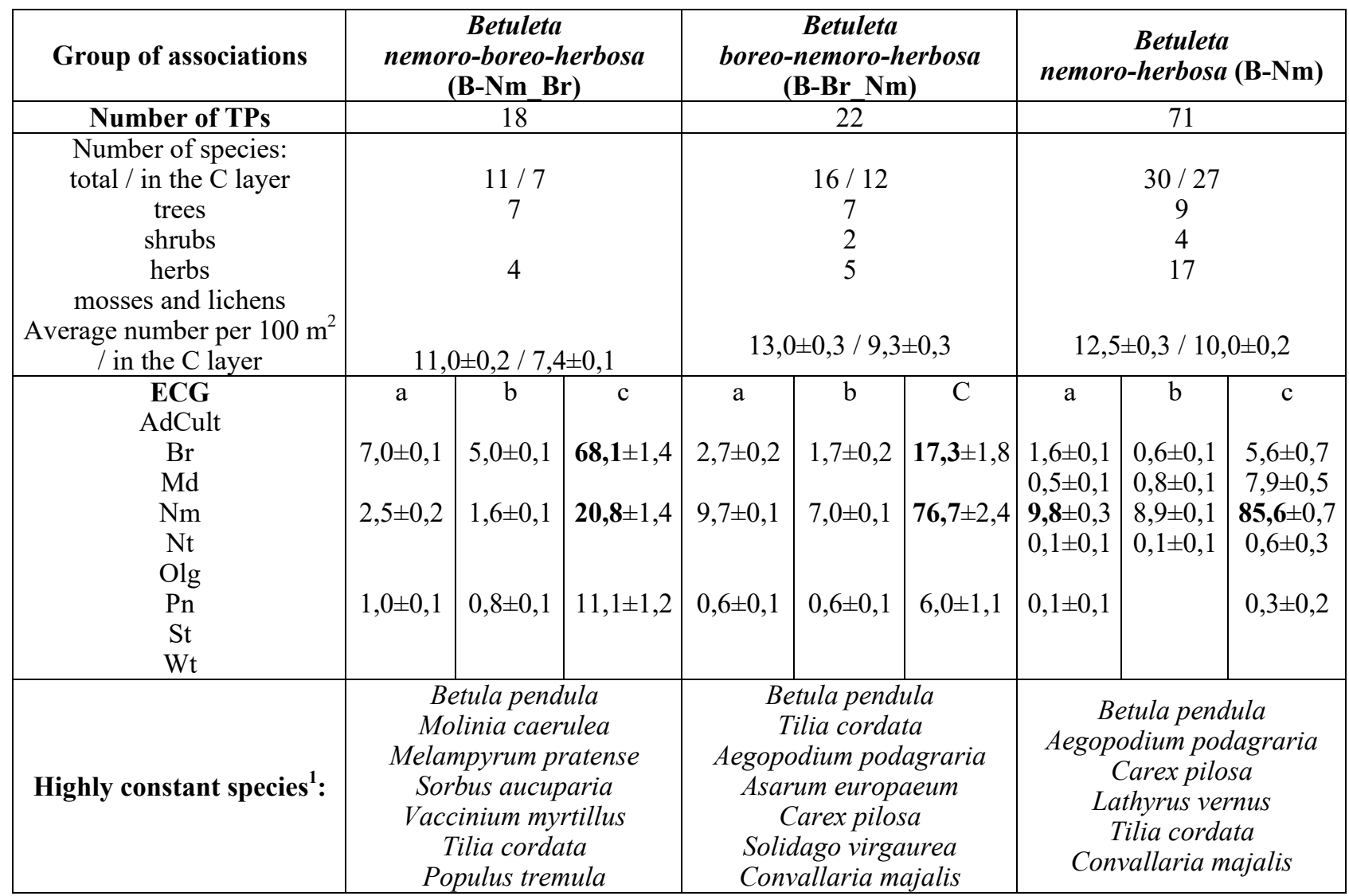

Plant communities of Betuleta boreo-nemoroherbosa $(\mathrm{B}-\mathrm{Br} \mathrm{Nm})$ are quite rare in the landscapes of water-glacial plains in the Penza region, they occupy small territories on the watershed surfaces of type 2 of locality. The stand is of complex structure: tree layer I formed by Betula pendula with a participation of single Populus tremula trees, layer II is formed by Tilia cordata. The undergrowth is well defined and formed by Corylus avellana with the participation of Euonymus verrucosa. Virginile undergrowth of Acer platanoides is typical. The grass-dwarf shrub layer is dominated by nemoral ECG species, i.e. Carex pilosa (dom.), Aegopodium podagraria, Asarum europaeum, Convallaria majalis, and Pulmonaria obscura. At the same time, boreal species such as Solidago virgaurea, Frangula alnus, and Sorbus aucuparia are found in the layer with high constancy, which makes it possible to classify these forests as a transition boreal-nemoral group.

Nemoral birch forests - Betuleta nemoroherbosa (B-Nm) predominate in the landscapes of water-glacial plains of the model territory: on the territory of type 1 locality, they occupy significant areas, especially on the near-watershed slopes, and occur in small areas on the watershed surfaces of type 1 and 2 localities (See Fig. 3). Despite the vast territories occupied by the communities of this group, they have a similar floral composition and structure. Nemoral birch forests share some characteristics of oak forests, the felling of which contributed to their formation Nemoral birch forests include Tilia cordata, which can also be abundant, is part of the undergrowth and often forms it entirely. The grass layer is dominated by nemoral species, with a predominance of Carex pilosa and co-dominance of Aegopodium podagraria.

The tree layer is formed by Betula pendula with a participation of singular Populus tremula trees. The undergrowth is formed by virginile Tilia cordata trees with varying degrees of closure. Linden has low projective cover, and Corylus avellana, Quercus robur, and occasionally Pyrus communis (on the upper elements of the relief, mainly of the southern direction) also take part in the layer. The grass-dwarf shrub layer is dominated by nemoral species. Carex pilosa (dom.), Aegopodium podagraria, Lathyrus vernus, Convallaria majalis, Convallaria majalis, Melica nutans, and Stellaria holostea show high constancy.

Oligotrophic birch forests - Betuleta olygotropho-herbosa (B-Olg) are confined to suffusion depressions on watershed surfaces of type 1 locality (See Fig. 3). The tree layer consists of Betula pubescens, sometimes with the participation of Pinus sylvestris. The stand is very thin. The undergrowth is poor expressed and formed by willow species Salix aurita and Salix myrsinifolia with Pi- 
nus sylvestris participation; sometimes there is no undergrowth. The grass layer is dominated by species of oligotrophic ECG with high participation of wetland species, boreal and nitrophilous are revealed. Sphagnum magellanicum, Calamagrostis canescens, and Eriophorum vaginatum are found with high constancy. The moss cover of Sphagnum magellanicum with the participation of Sphagnum fallax is well developed, Polytrichum commune is found along tree-trunk elevations. A distinctive feature of this group of associations is low species richness $-4-11$ species per $100 \mathrm{~m}^{2}$ as well as large floral and structural uniformity.

Black alder forests are found in floodplains of rivers and streams in all landscapes of waterglacial plains (See Fig. 4). According to the dominance of ECGs in the ground cover, the following groups of associations were identified: nitrophilous alder forests - Alneta nitrophilo-herbosa (A-Nt), nemoral-nitrophilous alder forests - Alneta nemoro-nitrophilo-herbosa (a-Nm_Nt), wetland alder forests - Alneta aqua-uliginoso-herbosa (A-Wt) (Table 5). The tree layer is formed by Alnus glutinosa, sometimes with an admixture of Populus tremula or Betula pendula. In some areas, there is tree layer II consisting of nemoral tree species Quercus robur and Tilia cordata.

Nitrophilous alder forests - Alneta nitrophiloherbosa (A-Nt) - is the largest group among alder forests in terms of the number of descriptions (See Table 5). Padus avium, Frangula alnus, and Ribes nigrum are often found in the undergrowth. Urtica dioica, Scirpus sylvaticus, Filipendula ulmaria, Deschampsia cespitosa, and Matteuccia struthiopteris are dominant in the grass cover, forming the corresponding associations.

Nemoral-nitrophilous alder forests - Alneta nemoro-nitrophilo-herbosa (A-Nm_Nt) occupy elevated areas of floodplains of forest rivers in the dells of near-watershed slopes of type 1 locality. More than $40 \%$ of the flora of these forests is made up of nitrophilous species, their share in the projective cover of the grass layer is more than $60 \%$ (See Table 5). The absence of long-term flooding contributes to the development of nemoral flora (participation in the projective cover of the grass layer is more than $30 \%$ ). The communities have well-formed undergrowth, dominated by Padus avium with the participation of Ribes nigrum, Salix caprea, Frangula alnus, Sorbus aucuparia, and, much less often - Corylus avellana. Ulmus glabra forms well-developed underbrush, and Tilia cordata undergrowth is present in some areas. Aegopodium podagraria and Urtica dioica are dominant in the grass layer, forming the corresponding associations.

Species diversity and highly constant species of groups

of associations, alder stand formation (Alneta glutinosa)

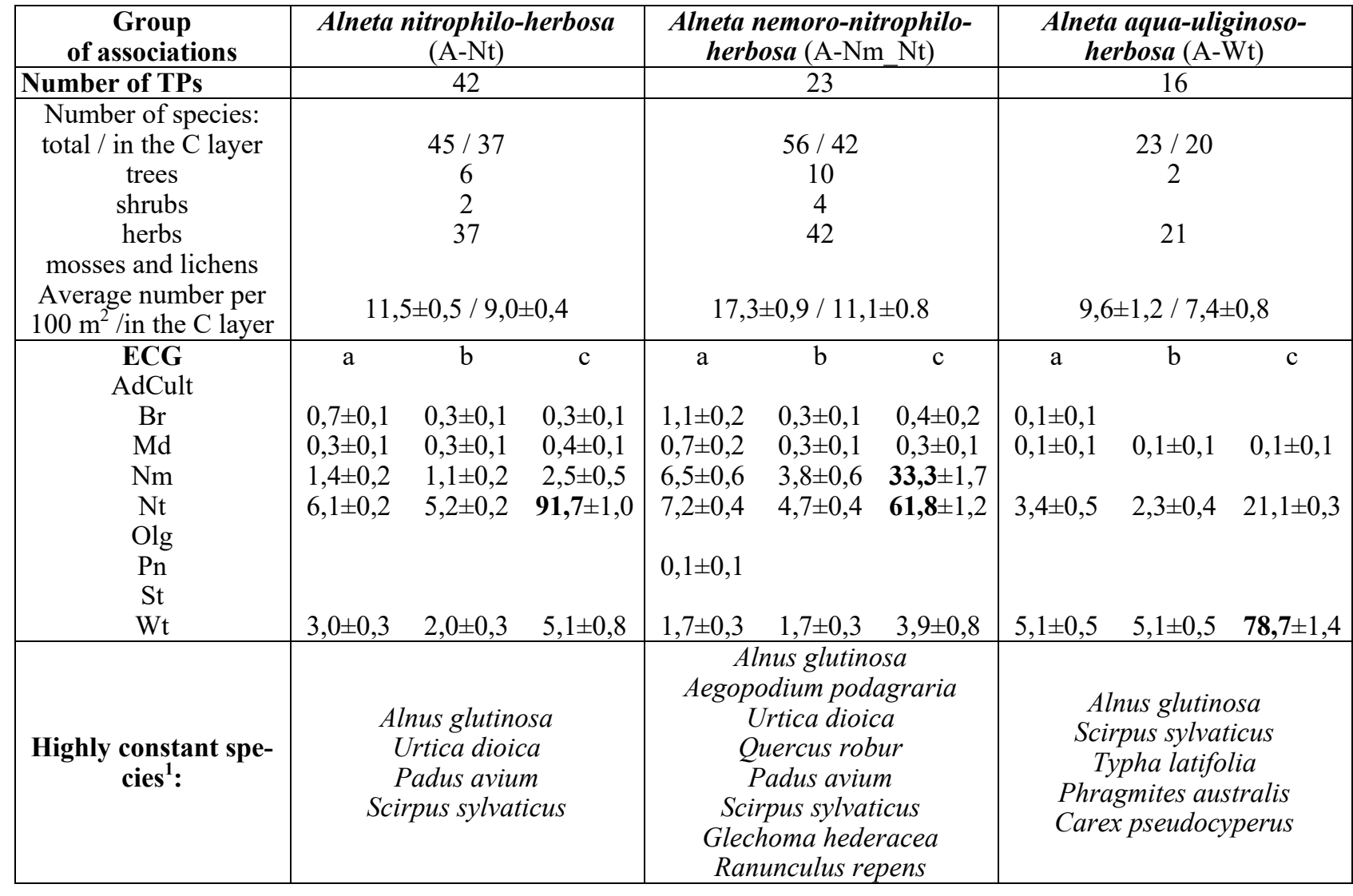


Note. $\mathrm{a}$ - the average number of species per TP in all layers; $b$ - the average number of species per TP in the $\mathrm{C}$ layer; $\mathrm{c}$ - the proportion of species in the $\mathrm{C}$ layer, taking into account the average abundance for the TP.

${ }^{1}$ - species constancy is calculated without considering layers; prevailing ECGs are highlighted in bold, taking into account the abundance of species.

Wetland alder forests - Alneta aqua-uliginosoherbosa (A-Wt) are confined to the floodplains of small rivers of the 2 nd type of locality (See Fig. 4), as well as to territories directly adjacent to the water edge. The group is represented by a small number of descriptions and is not often found in the landscapes of water-glacial plains. The dominant species in the grass cover are Carex pseudocyperus, Phragmites australis, and Carex acuta, which form the corresponding associations.

\section{Conclusions}

Intensive economic activity in the landscapes of water-glacial plains within the boundaries of the region has led to a significant transformation of vegetation cover. All communities are largely affected by economic activity, i.e. multiple logging, ploughing, grazing, and fires of varying intensity. Large areas (especially within type 2 locality) have been ploughed and converted into farmland.

Suffusion hollows and inter-hollow spaces on watersheds (type 1 locality) are occupied by forests (pine, birch, aspen forests) with boreal species dominating the grass-dwarf shrub layer.
Communities with high participation of nemoral ECG species are formed in interfluvial areas with shallow fluvioglacial deposits (type 2 locality).

The modern vegetation cover is dominated by derived (secondary) forests: birch $(42.5 \%)$ and aspen $(18.9 \%)$ forests, whereas pine forests occupy about $25.4 \%$ of the territory, and broad-leaved forests with a high participation of common oak account for $10.2 \%$. Linden and maple forests are only found as small areas (linden forests $-0.45 \%$, forests of Norway maple $-0.01 \%$ ). Black alder forests $(1.7 \%)$ grow near springs, streams, along the floodplains of small rivers, whereas willow forests $(0.03 \%)$ appear around swamps (mostly with traces of anthropogenic activity in terms of drainage). Siberian spruce $(0.06 \%)$, larch $(0.16 \%)$, common ash $(0.23 \%)$, poplars $(0.23 \%)$, and cedar $(0.01 \%)$ are also found.

Boreal pine forests are rare communities for the region. They include very rare species for the region, i.e. Rubus nessensis, Ledum palustre, and Calluna vulgaris.

\section{Библиографический список}

1. Артемова, С. Н. Морфологическая структура ландшафтов Окско-Донской равнины в пределах Пензенской области / С. Н. Артемова, Н. А. Леонова // Известия ПГПУ им. В. Г. Белинского. - 2011. - № 25. - С. 644-650.

2. Леонова, Н.А.Бореальные сосняки Окско-Донской равнины в пределах Пензенской области / Н. А. Леонова // Известия вузов. Поволжский регион. Естественные науки. - 2014. - № 2. - С. 57-67.

3. Artemova, S. Forest-steppe landscape organization of Eastern Europe (for example Penza region) / S. Artemova, N. Leonova // J. Wetlands Biodiversity. - 2014. - Vol. 4. - P. 147-152.

4. Определитель растений Тамбовской области / А. П. Сухоруков, С. А. Баландин, В. А. Агафонов, Ю. Е. Алексеев, И. О. Бузунова и др. ; под ред. А. П. Сухорукова. - Тула, 2010. - 350 с.

5. Васюков, В. М. Растения Пензенской области / В. М. Васюков. - Пенза : Изд-во ПГУ, 2004. - 184 с.

6. Алехин, В. В. Введение во флору Тамбовской губернии (Ботанический очерк) / В. В. Алехин. - Москва, 1915. $-97 \mathrm{c}$.

7. Географический атлас Пензенской области. - Пенза : Облиздат, 2005. - 60 c.

8. Черепанов, С. К. Сосудистые растения России и сопредельных государств (в пределах бывшего СССР). Русское издание / С. К. Черепанов. - Санкт-Петербург : Мир и семья, 1995. - 992 с.

9. Смирнова, О. В. Эколого-ценотические группы в растительном покрове лесного пояса Восточной Европы / О. В. Смирнова, Л. Г. Ханина, В. Э. Смирнов // Восточноевропейские леса: история в голоцене и современность. - Москва : Наука, 2004. - Кн. 1. - С. 165-175.

10. European Russian Forests. Their Current State and Features of Their History» / ed. by Olga Smirnova, Maxim Bobrovsky and Larisa Khanina. - 2017. - Ser. Plant and Vegetation/ - Vol. 15. - 566 p. - DOI 10.1007/978-94024-1172-0.

11. Миркин, Б. М. Растительность России в ареале синтаксономии Браун-Бланке: развитие подхода и результаты / Б. М. Миркин, А. И. Соломещ, С. Е. Журавлева // Журнал общей биологии. - 2000. - Т. 61, № 1. C. $5-21$.

12. Миркин, Б. М. Наука о растительности / Б. М. Миркин, Л. Г. Наумова. - Уфа : Гилем, 1998. 413 с.

13. Леонова, Н. А. Растительный покров и животный мир Окско-Донской равнины в пределах Пензенской области / Н. А. Леонова, В. Ю. Ильин // Известия вузов. Поволжский регион. Естественные науки. - 2017. № 1. - C. 57-67.

14. Красная книга Пензенской области. Ч. І. Грибы, лишайники, мхи, сосудистые растения / под ред. А. И. Иванова. - Пенза : Пензенская правда, 2013. - 300 с. 


\section{References}

1. Artemova S. N., Leonova N. A. Izvestiya PGPU im. V. G. Belinskogo [Proceedings of Penza State Pedagogical University]. 2011, no. 25, pp. 644-650. [In Russian]

2. Leonova N. A. Izvestiya vysshikh uchebnykh zavedeniy. Povolzhskiy region. Estestvennye nauki [University proceedings. Volga region. Natural Sciences]. 2014, no. 2, pp. 57-67. [In Russian]

3. Artemova S., Leonova N. J. Wetlands Biodiversity. 2014, vol. 4, pp. 147-152.

4. Sukhorukov A. P., Balandin S. A., Agafonov V. A., Alekseev Yu. E., Buzunova I. O. et al. Opredelitel' rasteniy Tambovskoy oblasti [Guide to plants of the Tambov region]. Tula, 2010, 350 p. [In Russian]

5. Vasyukov V. M. Rasteniya Penzenskoy oblasti [Plants of the Penza region]. Penza: Izd-vo PGU, 2004,184 p. [In Russian]

6. Alekhin V. V. Vvedenie vo floru Tambovskoy gubernii (Botanicheskiy ocherk) [Introduction to the flora of the Tambov governorate]. Moscow, 1915, 97 p. [In Russian]

7. Geograficheskiy atlas Penzenskoy oblasti [Geographical atlas of the Penza region]. Penza: Oblizdat, 2005,60 p. [In Russian]

8. Cherepanov S. K. Sosudistye rasteniya Rossii i sopredel'nykh gosudarstv (v predelakh byvshego SSSR). Russkoe izdanie [Vascular plants of Russia and adjacent states (former USSR). Russian edition]. Saint-Petersburg: Mir i sem'ya, 1995, 992 p. [In Russian]

9. Smirnova O. V., Khanina L. G., Smirnov V. E. Vostochnoevropeyskie lesa: istoriya v golotsene $i$ sovremennost [East European forests: history in the Holocene and modern times]. Moscow: Nauka, 2004, bk. 1, pp. 165-175. [In Russian]

10. European Russian Forests. Their Current State and Features of Their History». Ed. by Olga Smirnova, Maxim Bobrovsky and Larisa Khanina. 2017, Ser. Plant and Vegetation, vol. 15, 566 p. DOI 10.1007/978-94-024-1172-0.

11. Mirkin B. M., Solomeshch A. I., Zhuravleva S. E. Zhurnal obshchey biologii [Journal on general biology]. 2000, vol. 61, no. 1, pp. 5-21. [In Russian]

12. Mirkin B. M., Naumova L. G. Nauka o rastitel'nosti [Vegetation science]. Ufa: Gilem, 1998, 413 p. [In Russian]

13. Leonova N. A., Il'in V. Yu. Izvestiya vysshikh uchebnykh zavedeniy. Povolzhskiy region. Estestvennye nauki [University proceedings. Volga region. Natural sciences]. 2017, no. 1, pp. 57-67. [In Russian]

14. Krasnaya kniga Penzenskoy oblasti. Ch. I. Griby, lishayniki, mkhi, sosudistye rasteniya [Red Book of the Penza Region. Part 1. Mushrooms, lichens, mosses, vascular plants]. Ed. by A. I. Ivanov. Penza: Penzenskaya pravda, 2013, 300 p. [In Russian] 